\title{
Species composition and diversity, and carbon stock in a dune ecosystem in the Horqin Sandy Land of northern China
}

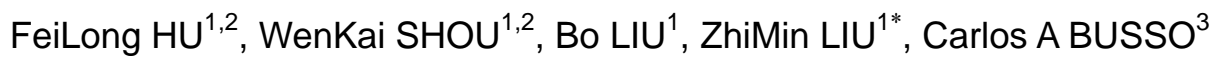 \\ ${ }^{1}$ State Key Laboratory of Forest and Soil Ecology, Institute of Applied Ecology, Chinese Academy of Sciences, Shenyang 110164, China; \\ ${ }^{2}$ University of Chinese Academy of Sciences, Beijing 100039, China; \\ ${ }^{3}$ Agronomy Department, National University of the South and CERZOS (CONICET), Bahía Blanca 8000, Argentina
}

\begin{abstract}
In this study, we determined carbon allocation and carbon stocks in the plant-soil system of different dune ecosystems in northeastern China. We quantified the species composition, above- and below-ground biomasses, and carbon stocks of three dune types (i.e. active dunes, semi-stabilized dunes and stabilized dunes) and their corresponding inter-dune lowlands (i.e. interdune lowlands of active dunes, interdune lowlands of semi-stabilized dunes and interdune lowlands of stabilized dunes) in the Horqin Sandy Land. The results showed that the succession series on interdune lowlands of the Horqin Sandy Land confirmed differences in species composition of the various dune types. Aboveground carbon (AGC) on the interdune lowlands of semi-stabilized dunes $\left(33.04 \mathrm{~g} \mathrm{C} / \mathrm{m}^{2}\right)$ was greater $(P<0.05)$ than that on the interdune lowlands of active dunes $\left(10.73 \mathrm{~g} \mathrm{C} / \mathrm{m}^{2}\right)$. At the same time, the different dune types did not show any significant differences $(P>0.05)$ in belowground plant carbon (BGC). However, the percentage of plant BGC in interdune lowlands of active dunes (81.5\%) was significantly higher $(P<0.05)$ than that in the interdune lowlands of semi-stabilized dunes $(58.9 \%)$. The predominant carbon pool in the study dune ecosystem was in the soil. It accounted for $95 \%$ to $99 \%$ of total carbon storage. Soil organic carbon $(\mathrm{SOC})$ was at least $55 \%$ greater $(P<0.05)$ in the interdunes than in the dunes. Stabilized dunes showed at least a $37 \%$ greater $(P<0.05)$ SOC content than active dunes up to a $1-m$ soil depth. Meanwhile, SOC content of interdune lowlands of semi-stabilized dunes was greater $(P<0.05)$ than that of interdune lowlands of active dunes only up to a $20-\mathrm{cm}$ soil depth. The dune ecosystem showed a great potential to store carbon when interdune lowlands of active dunes were conversed to interdune lowlands of semi-stabilized dunes, which stored up to twice as much carbon per unit volume as interdune lowlands of active dunes.
\end{abstract}

Keywords: species diversity; carbon storage; sand dunes; interdune lowlands; semi-arid areas

Citation: FeiLong HU, WenKai SHOU, Bo LIU, ZhiMin LIU, Carlos A BUSSO. 2015. Species composition and diversity, and carbon stocks in a dune ecosystem in the Horqin Sandy Land of northern China. Journal of Arid Land, 7(1): 82-93. doi: 10.1007/s40333-014-0038-0

The landscape of sand dunes is widely distributed in the world, covering $6 \times 10^{6} \mathrm{~km}^{2}$ of the world's land surface (Tropek et al., 2013). Eighty five percent of this surface is located in arid, inland regions of continents, and $15 \%$ along the banks of seas or rivers in humid regions (Tropek et al., 2013). Because of the importance of sand dunes in regulating the nutrient and carbon cycles, there was much interest in estimating plant biomass in the world's sand dunes
(Southgate et al., 1996; Renzhong et al., 2001; Emery and Doran, 2013). However, human activities (e.g. overcropping and deforestation) have contributed to desertification and degradation of these fragile sand dune ecosystems (Karl and Trenberth, 2003; Li et al., 2012).

Topographic depressions between dunes (i.e. inter dune lowlands) serve as "vegetation islands", which contribute significantly to the dynamic equilibrium of

\footnotetext{
*Corresponding author: ZhiMin LIU (E-mail: zmliu@iae.ac.cn)

Received 2014-01-02; revised 2014-06-03; accepted 2014-06-24

(C) Xinjiang Institute of Ecology and Geography, Chinese Academy of Sciences, Science Press and Springer-Verlag Berlin Heidelberg 2015
} 
partly vegetated dune fields (Liu et al., 2007). In fact, the habitat of interdune lowlands is more stable, and hardly interrupted by external factors, compared to that of dunes (Katoh et al., 1998; Wu et al., 2003).

Previous studies have paid more attention to carbon storage in dunes than that in interdune lowlands (Xie and Steinberger, 2005; Lu et al., 2012). Some studies had focused on interdune lowlands to determine soil seed bank (Zhai et al., 2009), appropriate grazing management (Katoh et al., 1998) and ecological restoration (Gang et al., 2012). However, carbon stock and species composition and diversity have been largely ignored in different interdune lowlands, (i.e. IL; e.g. interdune lowlands of active dunes, interdune lowlands of semi-stabilized dunes and interdune lowlands of stabilized dunes). Understanding the effect of interdune lowlands on carbon storage might provide a new insight into the effects of sand dune restoration in the global carbon cycle (Li et al., 2005; Miyasaka et al., 2011).

This study was carried out on both dunes and interdune lowlands in the Horqin Sandy Land of northeastern China for determining: 1) the extent which interdune lowlands affect species composition and diversity; 2) the differences of plant carbon allocation between dunes and interdune lowlands; and 3) the contribution of interdune lowlands to total carbon storage (plant-soil system) within the scope of dune restoration.

\section{Materials and methods}

\subsection{Study area}

This study, conducted within an 8 to 10 -year-exclosure to cultivation and herbivory grazing, was carried out in southwestern Horqin Sandy Land, Inner Mongolia, China $\left(42^{\circ} 56^{\prime}-43^{\circ} 20^{\prime} \mathrm{N}, 119^{\circ} 29^{\prime}-119^{\circ} 41^{\prime} \mathrm{E}\right.$; 428 to $494 \mathrm{~m}$ asl). The study area is characterized by sand dunes alternating with interdune lowlands, where overgrazing and extensive deforestation are the major factors leading to desertification (Kosmas and Danalatos, 1994).

The study area is characterized by a combination of temperate, semiarid and continental monsoonal climate. Average annual precipitation is $340 \mathrm{~mm}$, with
$70 \%-80 \%$ of it occurring between May and September. Annual mean open-pan evaporation is approximately $1,935 \mathrm{~mm}$. The annual temperature averages approximately $6.4^{\circ} \mathrm{C}$, with minimum or maximum mean monthly values in January $\left(-13.1^{\circ} \mathrm{C}\right)$ or July $\left(23.7^{\circ} \mathrm{C}\right)$, respectively. The annual mean wind velocity is in a range of 3.2 to $4.1 \mathrm{~m} / \mathrm{s}$, and the prevailing winds come from the northwest in winter and spring, and the southwest to south during summer and autumn (Zhang, 2004).

\subsection{Experimental design}

Samples were taken in mid-August 2010. The timing of sampling was similar to that of $\mathrm{Li}$ et al. (2005) in an area similar to ours. In the study region, three types of sand dunes (active dunes, semi-stabilized dunes, stabilized dunes) were selected, where additional interdune lowlands (interdune lowlands of active dunes, interdune lowlands of semi-stabilized dunes and interdune lowlands of stabilized dunes) were also chosen (Fig. 1). For each dune group, (e.g. active dunes and its corresponding interdune lowlands), six plots (500 $\mathrm{m} \times 500 \mathrm{~m}$ ) at least $2 \mathrm{~km}$ apart from each other were randomly established. In each plot, three subplots with an area of $1 \mathrm{~m} \times 1 \mathrm{~m}$ were set on each dune and its interdune lowland (Fig. 1). All aboveground plants were harvested close to the soil surface and species richness and biomass were recorded within each subplot. Meanwhile, three replicates of soil samples were taken with a $7-\mathrm{cm}$ diameter soil auger at $0-10,10-20,20-40$, 40-60, 60-80 and 80-100 cm soil depths, after the standing litter was collected. Away from $0.5-1.0 \mathrm{~m}$ nearby the soil samples were obtained, we dug another pit to a 1-m soil depth using spades and collected roots at each soil layer. Roots were collected following Ping et al. (2010).

Root and soil samples were transported to the laboratory, where soils were removed from roots after washing them manually with deionized water until thoroughly cleaned. Aerial shoots, litter and roots were oven-dried at $75^{\circ} \mathrm{C}$ to constant weight (i.e. approximately $72 \mathrm{~h}$ ), and then weighed. Soil samples were air-dried and thereafter sieved (2-mm mesh) to remove roots and other debris. For each soil sample, one sub-sample was oven-dried at $105^{\circ} \mathrm{C}$ for determining the gravimetric soil moisture and soil bulk 

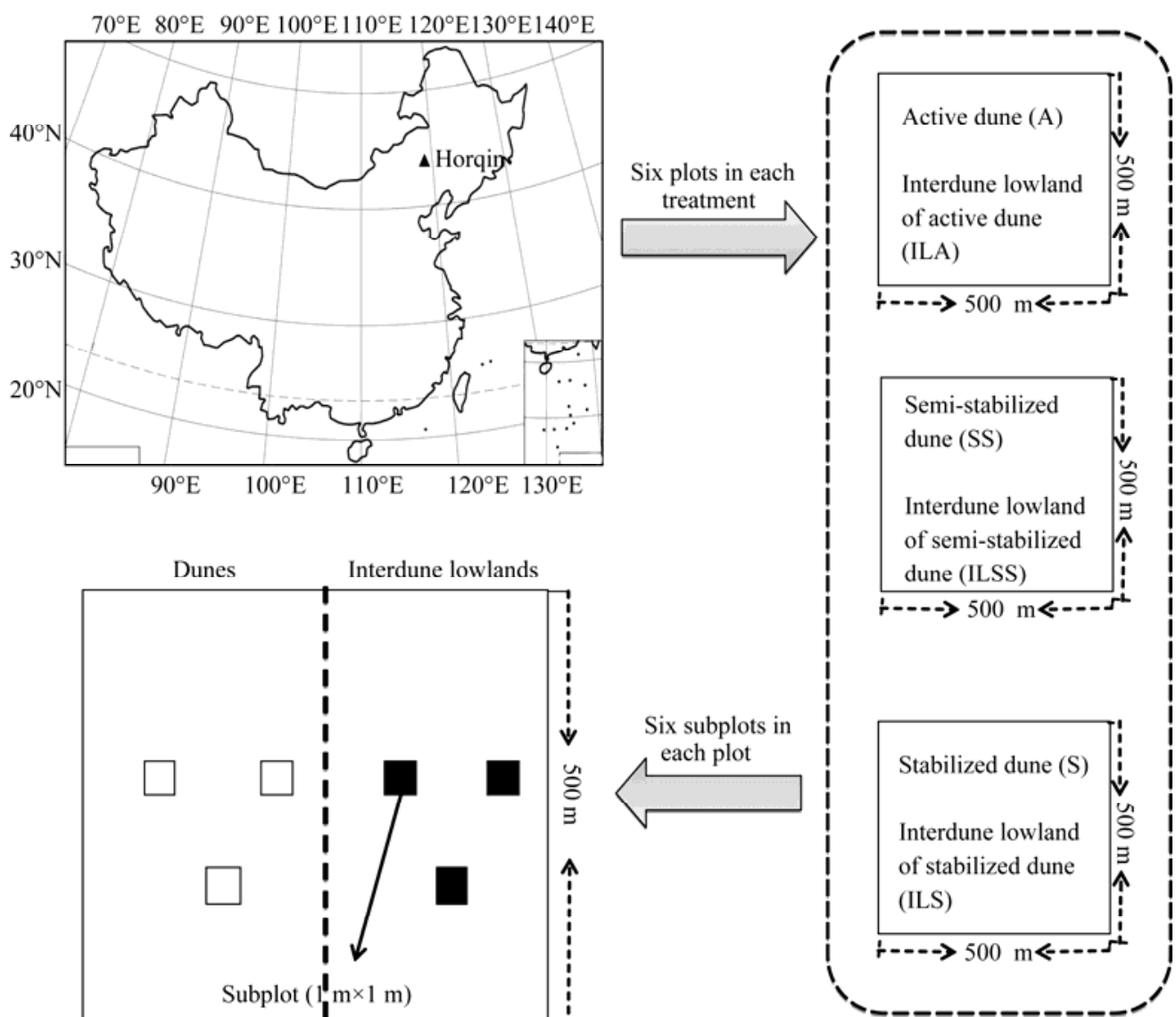

Fig. 1 The schematic diagram of sampling plots and experimental design on Horqin Sandy Land. The symbols are the same as in Figs. 2, 4 and 5 .

density following Brown (1995). The remaining soil sample was ground to pass $0.15-\mathrm{mm}$ sieve and it was then analyzed for soil organic carbon by the dichromate oxidation method of Walkey and Black (Nelson and Sommers, 1996).

Species diversity was calculated using the Simpson's Diversity Index (D) as:

$$
D=1-\sum_{i=1}^{s}\left(P_{i}\right)^{2} \text {. }
$$

Where $P_{i}$ is the proportion of the $i^{\text {th }}$ species in the community containing $s$ species (Simpson, 1949). This index represents the probability that two individuals randomly selected from a sample will belong to different species. The proportion (i.e. percentage) of each species biomass within each sample plot was first calculated with respect to the total biomass contribution of all species within that plot. This proportion was then expressed as a fraction (i.e. P) to use it in the formula of the Simpson's Diversity Index.
Carbon storage in plants was expressed as:

$$
B^{\prime}=B \times 45 \% \text {. }
$$

Where $B^{\prime}$ is carbon in the plant biomasses of the aboveground, belowground and litter components $\left(\mathrm{g} \mathrm{C} / \mathrm{cm}^{2}\right)$, and $B$ is the dry weight of the biomass samples (Crutzen and Andreae, 1990).

Soil organic carbon (SOC) was calculated following Tian et al. (2009):

$$
S O C_{t}=\sum S O C_{i}=\sum C_{i} D_{i} E_{i}\left(1-G_{i}\right) \times 100 .
$$

Where $S O C_{t}$ is the total value of soil organic carbon storage $\left(\mathrm{g} \mathrm{C} / \mathrm{m}^{2}\right) ; C_{i}$ is the concentration of soil organic carbon at the soil depth $i(\%) ; D_{i}$ is the soil bulk density $\left(\mathrm{g} / \mathrm{cm}^{3}\right) ; E_{i}$ is the thickness of soil layers $(\mathrm{cm})$; $G_{i}$ is the portion of gravel whose diameter is greater than $2 \mathrm{~mm}(\%)$.

\subsection{Statistical analysis}

In this paper, a dune and its interdune lowland were considered as a group. For example, the active dune group was represented by the active dune and its in- 
terdune lowland. Species composition was analyzed by detrended correspondence analysis (DCA). DCA was performed by Canoco (version 4.5, Canoco, Netherlands). Data were analyzed using one-way analysis of variance. Analysis was performed using a windows-based SPSS software (version 13, SPSS, Chicago, IL, USA) at a significant level of $P<0.05$. Differences among groups were compared using the LSD test (Steel and Torrie, 1960).

\section{Results}

\subsection{Species composition and diversity}

According to DCA analysis, the first two DCA axes explained $93.4 \%$ and $68.3 \%$, respectively, of the variability in the active dune groups, $70.3 \%$ and $38.0 \%$, respectively, of the variability in the semi-stabilized dune groups, and $53.5 \%$ and $25.6 \%$, respectively, of the variability in the stabilized dune groups (Fig. 2). Samples from active dunes (A1 to A6) showed a distinct cluster, having Agriophyllum squarrosum (L.) Moq. (AsriSqua) as the dominant species. There was no single dominant species in plots corresponding to the interdune lowlands of active dunes (Fig. 2a; Table 1). Corispermum stauntonii Moq. (CoriStau) and Pennisetum centrasiaticum Tzvel. (PennCent) showed a high affinity for interdune lowlands of semi-stabilized dune, whereas Calamagrostis epigejos (L.) Roth (CalaEpig), Cyperus fuscus L. (CypeFusc) and Setaria viridis (L.) P. Beauv (SetaViri) showed a high affinity for interdune lowlands of stabilized dunes (Fig. 2b). As the arrows for the groups of S1/S2, S3/S4, S5/S6 met nearly at right angles, these groups were predicted to have a low correlation (Fig. 2c). Nevertheless, the community of the interdune lowlands of semi-stabilized dunes showed a higher affinity, having Chenopodium acuminatum Willd. (ChenAcum), Corispermum stauntonii Moq. (ChriStau). and Setaria viridis (L.) P. Beauv. (SetaViri) as the dominant species.

Stabilized dunes showed a greater $(P<0.05)$ species diversity than that of semi-stabilized dunes and active dunes (Fig. 3). Interdune lowlands of stabilized and semi-stabilized showed a similar $(P>0.05)$ species diversity (Fig. 3). However, their values were greater $(P<0.05)$ than those of the interdune lowlands of active
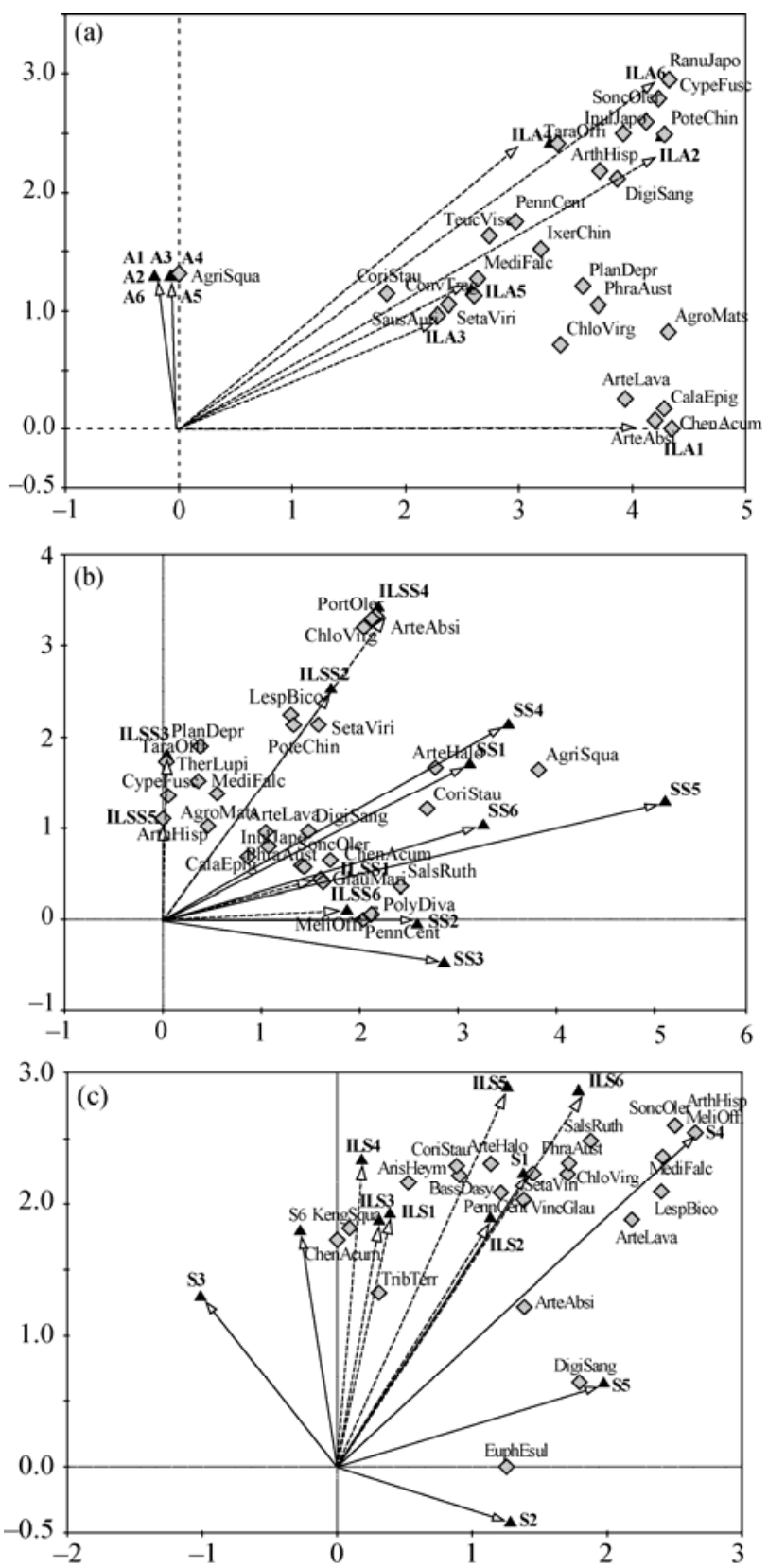

Fig. 2 Detrended correspondence analysis (DCA) of different treatments, where " $A$ " represents active dunes $(A)$ and interdune lowlands of active dunes (ILA), "B" represents semi-stabilized dunes (SS) and interdune lowlands of semi-stabilized dunes (ILSS), "C" represents stabilized dunes (S) and interdune lowlands of stabilized dunes (ILS). Species abbreviations (see Table 1) are nearby grey symbols; $\boldsymbol{\Delta}$ refers to plots of dunes or interdune lowlands. The solid lines point to dune types and the dashed lines point to their corresponding interdune lowlands from the coordinate origin. The horizontal and vertical axes are virtual axes which only point to possible variables.

dunes (Fig. 3). The diversity index was higher $(P<0.05)$ on the interdune lowlands than on dunes of the active 


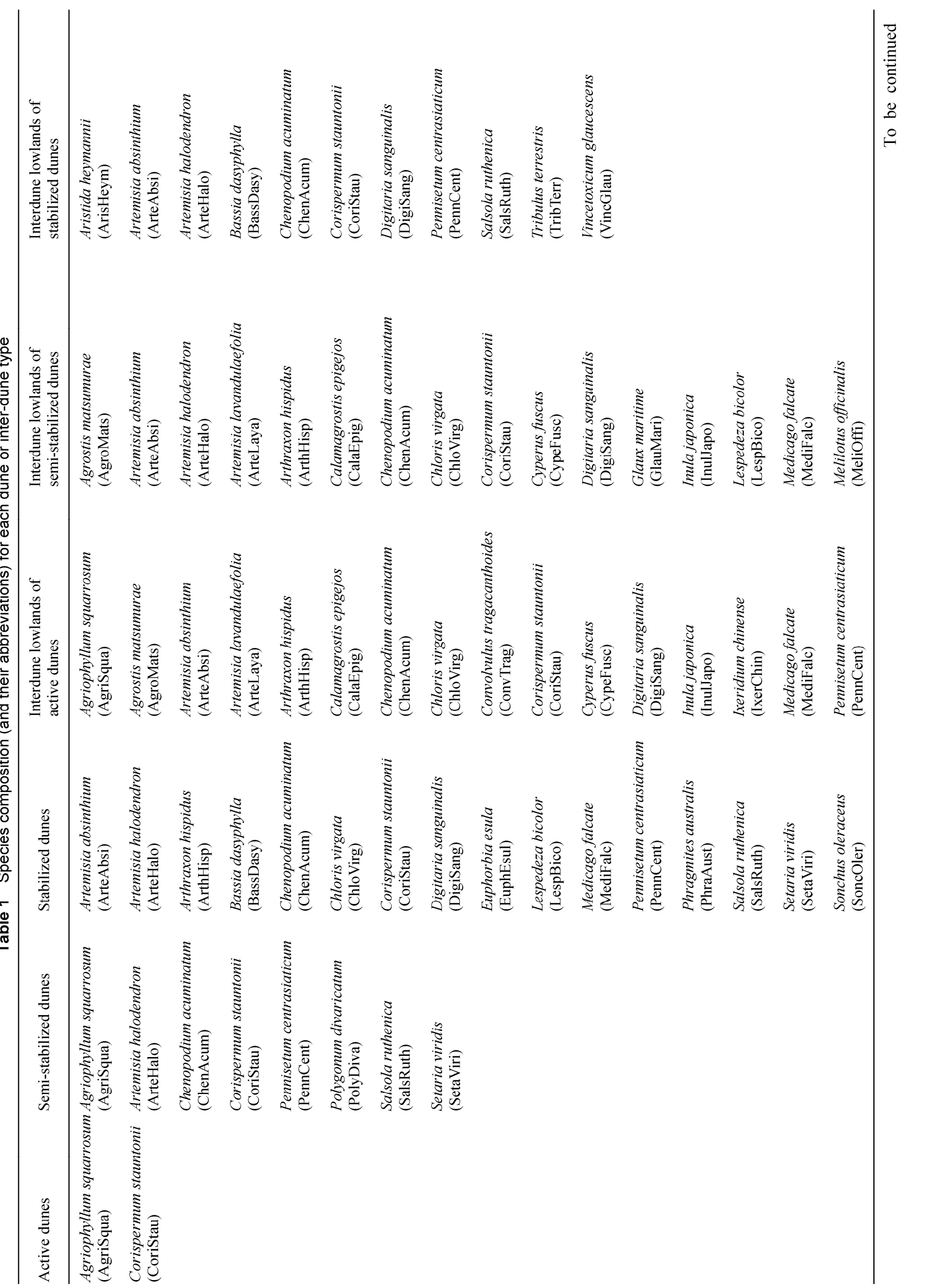




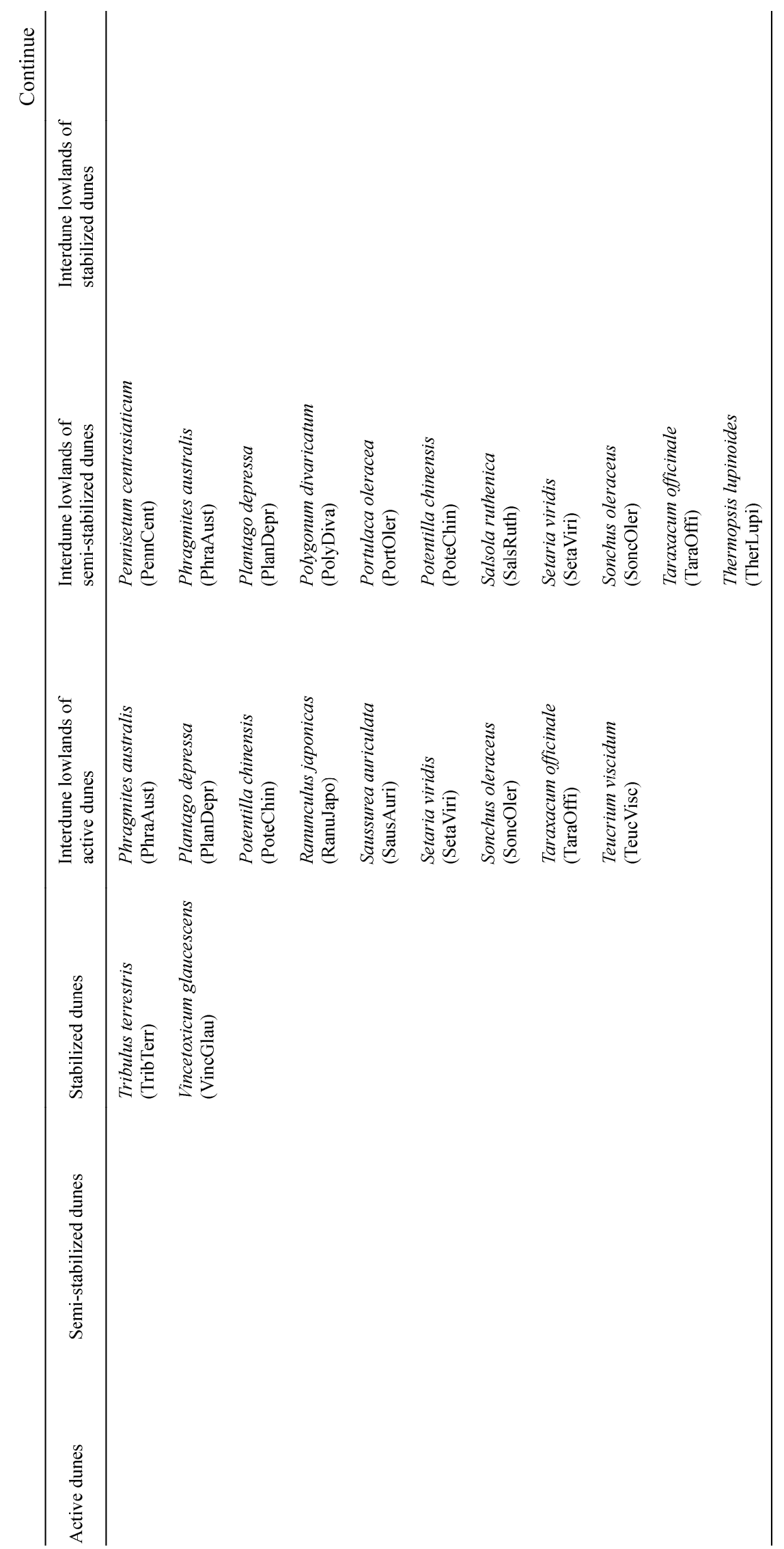




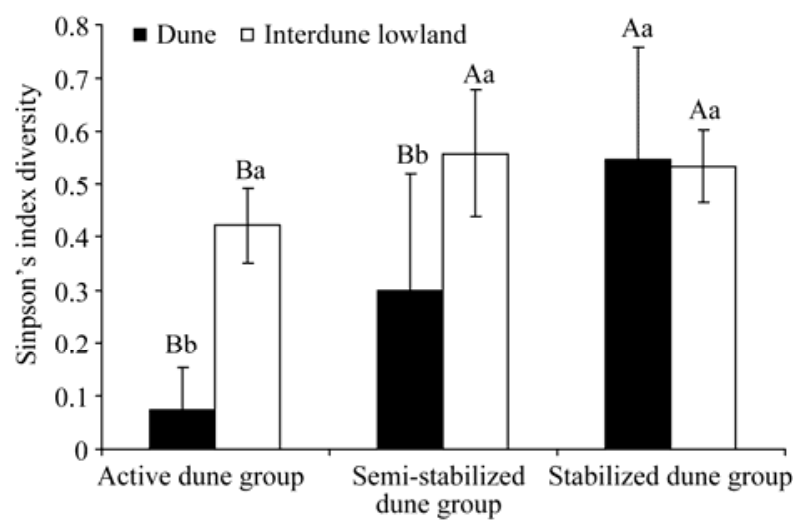

Fig. 3 Variation of the Simpson's Index of Diversity among the treatments. Each value is the mean \pm SE of $n=18$. Different uppercase letters above histograms indicate significant differences $(P<0.05)$ among dunes or interdune lowlands among dune groups. Lowercase letters show significant differences $(P<0.05)$ between each dune and its interdune lowland within each dune group.

and semi-stabilized dunes (Fig. 3). However, no significant $(P>0.05)$ differences were found between the interdune lowlands and the stabilized dunes (Fig. 3).

\subsection{Plant and soil carbon in different dunes and interdune lowlands}

No significant differences $(P>0.05)$ were found in the AGC and BGC between the semi-stabilized and stabilized dunes (Table 2). These values were greater $(P<0.05)$ than those showed in active dunes
$\left(\mathrm{AGC}=1.20 \pm 0.72 \mathrm{~g} \mathrm{C} / \mathrm{m}^{2} ; \mathrm{BGC}=4.12 \pm 7.12 \mathrm{~g} \mathrm{C} / \mathrm{m}^{2}\right)$. Percentage contribution of the AGC (2.04\%) and BGC (3.30\%) to total carbon storage was higher in the semi-stabilized dunes than in the active and stabilized dune types (Table 2). Carbon on litter was significantly higher $(P<0.05)$ on the stabilized dunes than on the semi-stabilized and active dunes (Table 2). The trend in the content of SOC $(P<0.05)$ was stabilize dunes $>$ semi-stabilized dunes $>$ active dunes (Table 2).

Aboveground- and litter-carbon (LC) contents were significantly greater $(P<0.05)$ on the interdune lowlands of stabilized dunes than on the interdune lowlands of active dunes (Table 2). Belowground carbon content, however, was similar $(P>0.05)$ among the three kinds of interdune lowlands (Table 2). Soil organic carbon was similar $(P>0.05)$ in the interdune lowlands of stabilized dunes and interdune lowlands of semi-stabilized dunes (Table 3 ). These values, however, were greater $(P<0.05)$ than those in the interdune lowlands of active dunes (Table 3 ).

The trend in total carbon storages for different dunes $(P<0.05)$ was stabilized dunes $>$ semi-stabilized dunes $>$ active dunes (Table 2). Interdune lowlands showed a similar $(P<0.05)$ total carbon storage in the stabilized dunes and semi-stabilized dunes (Table 3). These values, however, were greater $(P<0.05)$ than those in interdune lowlands of active dunes (Table 3).

Table 2 Carbon storage of three different dune types

\begin{tabular}{|c|c|c|c|c|c|}
\hline \multirow{2}{*}{ Treatment } & \multicolumn{3}{|c|}{ Plant carbon content $\left(\mathrm{g} \mathrm{C} / \mathrm{m}^{2}\right)$} & \multirow{2}{*}{$\begin{array}{l}\text { SOC content } \\
\left({\left.\mathrm{g} \mathrm{C} / \mathrm{m}^{2}\right)}^{-}\right.\end{array}$} & \multirow{2}{*}{$\begin{array}{l}\text { Total carbon storage } \\
\qquad\left(\mathrm{g} \mathrm{C}^{2} \mathrm{~m}^{2}\right)\end{array}$} \\
\hline & AGC & BGC & LC & & \\
\hline A & $1.20 \pm 0.72^{\mathrm{b}}$ & $4.12 \pm 7.12^{\mathrm{b}}$ & $0.86 \pm 0.40^{\mathrm{b}}$ & $511.94 \pm 94.58^{\mathrm{c}}$ & $518.13 \pm 96.14^{\mathrm{c}}$ \\
\hline SS & $22.66 \pm 23.83^{\mathrm{ab}}$ & $36.74 \pm 26.00^{\mathrm{a}}$ & $9.47 \pm 10.51^{\mathrm{b}}$ & $1,043.77 \pm 304.52^{\mathrm{b}}$ & $1,112.64 \pm 287.71^{\mathrm{b}}$ \\
\hline S & $26.42 \pm 26.29^{\mathrm{a}}$ & $48.56 \pm 17.39^{\mathrm{a}}$ & $21.46 \pm 8.29^{\mathrm{a}}$ & $2,174.16 \pm 735.96^{\mathrm{a}}$ & $2,270.60 \pm 747.24^{\mathrm{a}}$ \\
\hline
\end{tabular}

Note: Each value is the mean \pm SE of $n=18$. Different letters in the same column indicate significant differences $(P<0.05)$ among different dune types. AGC, aboveground carbon; BGC, belowground carbon; LC, litter carbon; SOC, soil organic carbon. A, active dunes; SS, semi-stabilized dunes; S, stabilized dunes.

Table 3 Carbon storage of three different interdune lowlands

\begin{tabular}{|c|c|c|c|c|c|}
\hline \multirow{2}{*}{ Treatment } & \multicolumn{3}{|c|}{ Plant carbon content $\left(\mathrm{g} \mathrm{C} \mathrm{m}^{2}\right)$} & \multirow{2}{*}{$\begin{array}{l}\text { SOC content } \\
\left(\mathrm{g} \mathrm{C}^{2} \mathrm{~m}^{2}\right)\end{array}$} & \multirow{2}{*}{$\begin{array}{l}\text { Total carbon storage } \\
\left(\mathrm{g} \mathrm{C} / \mathrm{m}^{2}\right)\end{array}$} \\
\hline & AGB & BGB & LC & & \\
\hline ILA & $10.73 \pm 5.38^{\mathrm{b}}$ & $55.71 \pm 24.57^{\mathrm{a}}$ & $11.15 \pm 6.21^{\mathrm{b}}$ & $2,125.50 \pm 827.69^{b}$ & $2,203.09 \pm 818.92^{\mathrm{b}}$ \\
\hline ILSS & $19.34 \pm 13.79^{\mathrm{ab}}$ & $80.07 \pm 95.46^{\mathrm{a}}$ & $25.50 \pm 13.53^{\mathrm{ab}}$ & $4,396.68 \pm 1593.63^{\mathrm{a}}$ & $4,521.58 \pm 1566.17^{\mathrm{a}}$ \\
\hline ILS & $33.04 \pm 17.86^{\mathrm{a}}$ & $45.72 \pm 15.70^{\mathrm{a}}$ & $38.50 \pm 17.17^{\mathrm{a}}$ & $4,261.06 \pm 1304.53^{\mathrm{a}}$ & $4,378.32 \pm 1328.25^{\mathrm{a}}$ \\
\hline
\end{tabular}

Note: Each value is the mean $\pm \mathrm{SE}$ of $n=18$. Different letters in the same column indicate significant differences $(P<0.05)$ among interdune lowlands on each of the different dune types. AGC, aboveground carbon; BGC, belowground carbon; LC, litter carbon; SOC, soil organic carbon; ILA, interdune lowlands of active dunes; ILSS, interdune lowlands of semi-stabilized dunes; ILS, interdune lowlands of stabilized dunes. 
The contribution of soil $\mathrm{C}$ to total $\mathrm{C}$ storage in the plant-soil system was greater than $93 \%$ in all dunes and its corresponding interdunes (Tables 2 and 3). This is, most of the $\mathrm{C}$ in the plant-soil system was in the soil as organic carbon (Tables 2 and 3).

The different dune types (active dunes, semi-stabilized dunes and stabilized dunes) did not show significant differences $(P>0.05)$ in the partitioning of neither BGC nor AGC (Fig. 4). However, BGC was significantly greater $(P<0.05)$ in the interdune lowlands of active dunes $(81.5 \%)$ than in the interdune lowlands of stabilized dunes $(58.9 \%)$, while AGC was significantly greater $(P<0.05)$ on the interdune lowlands of stabilized dunes than on the interdune lowlands of active dunes (Fig. 4).

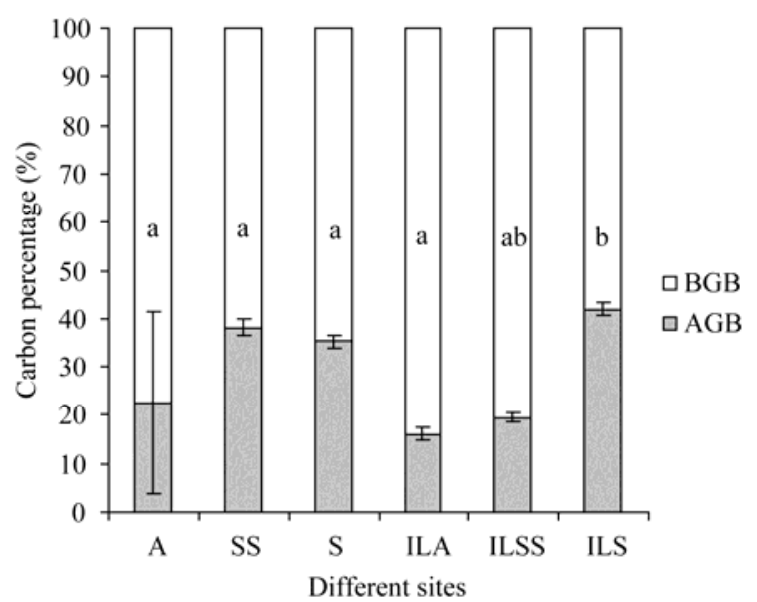

Fig. 4 Percentage of aboveground- or belowground-carbon to total plant carbon (excluding litter) for each dune type and its corresponding interdune lowland. Each value is the mean \pm SE for $\mathrm{AGC}$, and the mean for BGC, of $n=18$. Different letters above histograms indicate significant differences $(P<0.05)$ in both AGC and BGC among either dune or interdune lowland types.

\subsection{Distribution of carbon at different soil depths}

Interdune lowlands tended to have a greater SOC than all studied dune types (Fig. 5). Stabilized dunes showed a higher $(P<0.05)$ SOC than active dunes in all soil depths (Fig. 5). Even more, semi-stabilized dunes had a greater $(P<0.05)$ SOC than active dunes at $40-80 \mathrm{~cm}$ soil depth (Fig. 5). Interdune lowlands of stabilized and semi-stabilized dunes showed a greater $(P<0.05)$ SOC than that of the interdune lowlands of active dunes up to a 20 -cm soil depth (Fig. 5). Thereafter, no significant differences $(\mathrm{P}>0.05)$ were found between the interdune lowlands of all dune types at 40-100 cm soil depth (Fig. 5).

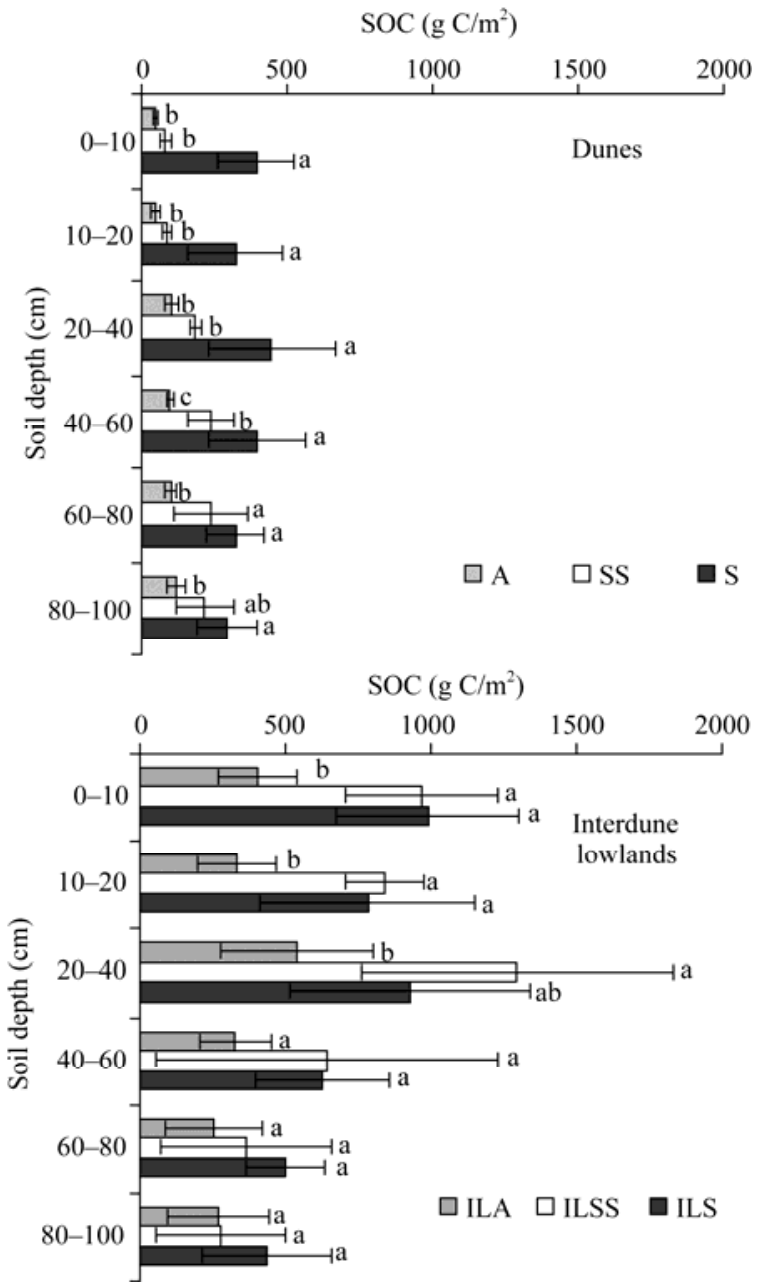

Fig. 5 Soil carbon storage at different soil depths for different dune types or their interdune lowlands. Each value is the mean \pm SE of $n=18$. Within each soil depth for dune types or their interdunes, different letters indicate significant differences at $P<0.05$.

\section{Discussion}

\subsection{Species composition and diversity}

Earlier pioneer species are the first to colonize the bare ground and the habitats are with very poor soils, and are more sensitive to environmental changes (Santoro et al., 2011). These pioneer species are progressively replaced as succession proceeds, and create opportunities for the appearance of later-successional species (Swaine and Whitmore, 1988; Cheesman and Winter, 2013). In our study, active dune was characterized by the pioneer species Agriophyllum squarrosum (L.) Moq., which is consistent with previous studies (Zhang et al., 2005; Zuo et al., 2008). However, 
some studies on dune ecosystems have identified different pioneer communities, such as that of Corynephorus canescens in the northern upper Rhine Valley of Germany (Sü $\beta$ et al., 2004). As active dunes transformed to stabilized dunes, later's successional species such as Chenopodium acuminatum Willd (Huang et al., 2012) and Setaria viridis (L.) P. Beauv. in stabilized dunes, or Corispermum mongolicum Iljin, Chenopodium acuminatum Willd and Setaria viridis (L.) P. Beauv. in interdune lowlands of stabilized dunes, appeared as dominant species.

The similarity of distribution among the samples presumably reflects the similarity in their ecological responses (Braak, 1989; Gilliam and Saunders, 2003). The succession series of interdune lowlands in the Horqin Sandy Land showed differences in species composition with the dune types (Fig. 2). At the beginning of primary succession, species composition of active dunes was generally uniform, whereas interdune lowlands of active dunes produced a similar species composition except for one plot (interdune lowlands of active dunes). In the middle of the succession period, both stabilized dunes and interdune lowlands of semi-stabilized dunes contributed a wider range of species composition. Moreover, in the later succession period, species composition of interdune lowlands of semi-stabilized dunes demonstrated a stable situation, while great differences were found in stabilized dunes (from S1 to S6). Many factors seem to be involved in dune succession, such as vegetation heterogeneity, nutrient flux and retention and seedling establishment (Morrison and Yarranton, 1974; Kellman and Roulet, 1990; Santana et al., 2012).

The belief that natural ecosystems become more diverse and more stable with time after a disturbance is widely accepted and regularly repeated in many studies (Orians, 1975; Jactel et al., 2005; Isermann, 2011). In our study, the species diversity showed the following trend: stabilized dune $(D=0.55)>$ semi-stabilized dune $(D=0.30)>$ active dune $(D=0.07)$. The fact that the habitat of interdune lowlands is more stable and rarely constrained by environmental factors, compared to that of dunes (Katoh et al., 1998; Wu et al., 2003) might help to explain that interdune lowlands of semi-stabilized dunes and interdune lowlands of stabilized dunes showed a similar species diversity.

\subsection{Plant and soil carbon in different dunes and interdune lowlands}

Soil carbon storage is widely studied in the fields of biodiversity protection and ecological restoration (Bonan et al., 1992; Melillo et al., 1993; Kramer et al., 2012). Carbon contained in terrestrial soil has been reported to be almost twice or even three times as much as that in plants (Post and Kwon, 2000). According to our study, the percentage of soil carbon in dune ecosystems with respect to total carbon in the plant-soil system was even higher, contributing the lowest of $93.81 \%$ in stabilized dunes and the highest of $98.81 \%$ in active dunes (Table 2). Soil carbon of interdune lowlands contributed more than $96 \%$ of the total carbon pool (Table 3). Belowground carbon contributed with the highest proportion among the studied plant components. Xiao et al. (2007) reported that the increased addition of particulate organic matter belowground (and the associated nutrient release) had a large effect on soil microbial biomass and activity, largely affecting plant growth. They suggested that the response of plant productivity to that addition might indicate that plant productivity is primarily limited by nutrients and not by water, while microbial activity is energy-limited, in the semiarid grassland ecosystems of northern China.

Stabilized and semi-stabilized sand dunes account for $70 \%$ of the entire sand dunes in northern China (Zhang et al., 2012). Thus, it is important to study the carbon stocks of the two sand dune types (Elbert et al., 2012; Kabuyah et al., 2012). When active dunes are converted to semi-stabilized or stabilized dunes, interdune lowlands of active dunes will also be transformed to interdune lowlands of semi-stabilized dunes or interdune lowlands of stabilized dunes, respectively. In Horqin Sandy Land, when active dunes were converted to stabilized dunes, the carbon storage of dune ecosystems included two parts: (1) active dunes (518.13 $\mathrm{g} \mathrm{C} / \mathrm{m}^{2}$ ) would be transformed to stabilized dunes $\left(2,270.60 \mathrm{~g} \mathrm{C} / \mathrm{m}^{2}\right)$, and (2) interdune lowlands of active dunes $\left(2,203.09 \mathrm{~g} \mathrm{C} / \mathrm{m}^{2}\right)$ would be transformed to interdune lowlands of stabilized dunes $\left(4,378.32 \mathrm{~g} \mathrm{C} / \mathrm{m}^{2}\right)$, which produced 8 times the carbon storage of active dunes. Therefore, for the estimation of carbon storage in dune ecosystems, it is imperative to take into account not only the study dune types, but 
also their associated interdune lowlands. Also, Zheng et al. (2004) reported that soil physical-chemical characteristics and soil fertility overall, increased when shifting dunes (i.e. active) were converted to stabilized dunes in the Tengger Desert of China.

The greater belowground than aboveground plant carbon in all study environments (Tables 2 and 3) might be an evolutionary strategy that allows these plants to establish and survive under hostile environments (Duarte et al., 1998; Jassey et al., 2013). Some studies suggested that plants on active dunes may display a higher proportion of belowground carbon when they are exposed to wind erosion (Brown, 1997; Bessler et al., 2009). Our study, however, indicated that the percentage of belowground plant carbon showed no significant differences among the different dune types (Fig. 4). On the contrary, the percentage of belowground carbon in the interdune lowlands of active dunes contributed the highest among the different interdune lowlands: the belowground carbon proportion was significantly higher in the interdune lowlands of active dunes than in the interdune lowlands of stabilized dunes or interdune lowlands of semi-stabilized dunes. Luo et al. (2014) found that discrete components of root exudates affected soil physical-chemical conditions differently, and responses to root exudates in soils with low carbon contents can differ from those in normal soils. Their results indicated a potential for acid root exudates to decrease decomposition rate of soil organic matter in low carbon soils, which is of interest for both soil restoration and carbon sequestration. These results might help to explain the similar or greater plant belowground carbon proportions in the active dunes than in the stabilized dunes of the study dune ecosystem.

\subsection{Carbon distribution at different soil depths}

The distribution pattern of soil carbon can be a key element in shaping nutrient flows in dune ecosystems, and its identification is relevant for understanding degradation processes in these areas (Jobbágy and Jackson, 2000). The content of SOC was consistently greater in the stabilized dunes than in the active dunes up to a 1-m soil depth. Our results are somehow similar to those of Wang et al. (2006), who reported that the carbon content was $66 \%$ greater in non-degraded than in degraded soils in northern China. On the other hand, interdune lowlands of stabilized dunes showed a greater SOC content than that of interdune lowlands of active dunes only up to a $20-\mathrm{cm}$ soil depth, and it was extended up to a $40-\mathrm{cm}$ soil depth when SOC was greater on interdune lowlands of semi-stabilized dunes than on interdune lowlands of active dunes.

Soil organic carbon was lower in all dune types than in their interdune lowlands. These results are in agreement with those of Zheng et al. (2004), who showed that the accumulated amount of organic matter and various soil nutrients were higher in interdune depressions than in their surrounding dunes.

\section{Conclusion}

Our study provided further evidence that the semi-arid dune ecosystems in China, where the soil was the major carbon pool, provided more carbon stock per unit area when dunes were converted from active to stabilized. The greater carbon content in interdune lowlands compared with their associated dunes highlights the importance of studying the interdune lowlands when estimating soil carbon storage in dune ecosystems.

\section{Acknowledgements}

This research was financially supported by the National Basic Research Program of China (2013CB429905-01). The author, Carlos A BUSSO thanks (1) the sabbatical leave given by Agronomy Department, National University of the South and CERZOS (CONICET), (2) the associateship awarded by the Third World Academy of Sciences (TWAS)- UNESCO, and (3) housing, facilities and financial support from the Institute of Applied Ecology, Chinese Academy of Sciences. The authors also thank QuanLai ZHOU, XueHua LI, YongMin LUO and ChengYou CHAO for their help in field work.

\section{References}

Acharya B S, Rasmussen J, Eriksen J. 2012. Grassland carbon sequestration and emissions following cultivation in a mixed crop rotation. Agriculture, Ecosystems \& Environment, 153(15): 33-39.

Bessler H, Temperton V M, Roscher C, et al. 2009. Aboveground overyielding in grassland mixtures is associated with reduced biomass partitioning to belowground organs. Ecology, 90(6): $1520-1530$

Bonan G B, Pollard D. 1992. Vegetation on global climate. Nature, 359: 
716-718.

Brown J F. 1997. Effects of experimental burial on survival, growth, and resource allocation of three species of dune plants. Journal of Ecology, 85(2): 151-158.

Brown J H, Valone T J, Curtin C G. 1997. Reorganization of an arid ecosystem in response to recent climate change. Proceedings of the National Academy of Sciences, USA, 94(18): 9729-9733.

Brown R W. 1995. Wildland Plants: Physiological Ecology and Developmental Morphology. Denver: Society for Range Management, 291-413

Cheesman A W, Winter K. 2013. Elevated night-time temperatures increase growth in seedlings of two tropical pioneer tree species. New Phytologist, 197(4): 1185-1192.

Conti G, Díaz S. 2013. Plant functional diversity and carbon storage-an empirical test in semi-arid forest ecosystems. Journal of Ecology, 101(1): 18-28.

Crutzen P J, Andreae M O. 1990. Biomass burning in the tropics: Impact on atmospheric chemistry and biogeochemical cycles. Science, 250(4988): 1669-1678.

Duan Z H, Xiao H L, Li X R, et al. 2004. Evolution of soil properties on stabilized sands in the Tengger Desert, China. Geomorphology, 59(1-4): 237-246.

Duarte C M, Merino M, Agawin N S R, et al. 1998. Root production and belowground seagrass biomass. Marine Ecology Progress Series, 171: 97-108.

Elbert W, Weber B, Burrows S, et al. 2012. Contribution of cryptogamic covers to the global cycles of carbon and nitrogen. Nature Geoscience, 5: 459-462.

Gilliam F S, Saunders N E. 2003. Making more sense of the order: A review of Canoco for Windows 4.5, PC-ORD version 4 and SYN-TAX 2000. Journal of Vegetation Science, 14: 297-304.

Högberg P. 2012. What is the quantitative relation between nitrogen deposition and forest carbon sequestration? Global Change Biology, 18(1): $1-2$.

Huang G, Zhao X Y, Li Y Q, et al. 2012. Restoration of shrub communities elevates organic carbon in arid soils of northwestern China. Soil Biology and Biochemistry, 47: 123-132.

Huang Y X, Zhao X Y, Zhou D W, et al. 2012. Phenotipic plasticity of early and late successional forbs in response to shifts in resources. Plos One, 7(11): e50304.

Isermann M. 2011. Patterns in species diversity during succession of coastal dunes. Journal of Coastal Research, 27(4): 661-671.

Jactel H, Brockerhoff E, Duelli P. 2005. Effects of experimental burial on survival, growth, and resource allocation of three species of dune plants. Forest Diversity and Function, 85(2): 151-158.

Jassey V E, Chiapusio G, Binet P, et al. 2013. Above- and belowground linkages in Sphagnum peatland: climate warming affects plant-microbial interactions. Global Change Biology, 19(3): 811-823.

Jobbágy E G, Jackson R B. 2000. The vertical distribution of soil organic carbon and its relation to climate and vegetation. Ecological Applications, 10(2): 423-436.

Kabuyah R N, Van Dongen B E, Bewsher A D, et al. 2012. Decomposition of lignin in wheat straw in a sand-dune grassland. Soil Biology and Biochemistry, 45: 128-131.
Karl T R, Trenberth K E. 2003. Modern global climate change. Science, 302(5651): 1719-1723.

Katoh K, Takeuchi K, Jiang D, et al. 1998. Vegetation restoration by seasonal exclosure in the Kerqin Sandy Land, Inner Mongolia. Plant Ecology, 139(2): 133-144.

Kellman M, Roulet N. 1990. Nutrient flux and retention in a tropical sand-dune succession. The Journal of Ecology, 78(3): 664-676.

Kramer M G, Sanderman J, Chadwick O A, et al. 2012. Long-term carbon storage through retention of dissolved aromatic acids by reactive particles in soil. Global Change Biology, 18(8): 2594-2605.

Li X R, Zhang P, Su Y Z, et al. 2012. Carbon fixation by biological soil crusts following revegetation of sand dunes in arid desert regions of China: A four-year field study. Catena, 97: 119-126.

Li Y L, Johnson D A, Su Y Z, et al. 2005. Specific leaf area and leaf dry matter content of plants growing in sand dunes. Botanical Bulletin of Academia Sinica, 46: 127-134.

Liu Z M, Li X L, Yan Q L, et al. 2007. Species richness and vegetation pattern in interdune lowlands of an active dune field in Inner Mongolia, China. Biological Conservation, 140(1-2): 29-39.

Lu H Y, Zhou Y L, Liu W G, et al. 2012. Organic stable carbon isotopic composition reveals late Quaternary vegetation changes in the dune fields of northern China. Quaternary Research, 77(3): 433-444.

Luo Y Q, Zhao X Y, Andrén O, et al. 2014. Artificial root exudates and soil organic carbon mineralization in a degraded sandy grassland in northern China. Journal of Arid Land, 6(4): 423-431.

Melillo J M, Mcguire A D, Kicklighter D W, et al. 1993. Global climate change and terrestrial net primary production. Nature, 363: 234-240.

Miyasaka T, Okuro T, Zhao H, et al. 2011. Impacts of the local land-use system in a semi-arid region of northeastern China on soil properties, crop growth, and weed communities. Journal of Arid Environments, 75(11): 1155-1163.

Morrison R, Yarranton G. 1974. Vegetational heterogeneity during a primary sand dune succession. Canadian Journal of Botany, 52(2): 397-410.

Nelson D W, Sommers L E, Sparks D, et al. 1996. Methods of Soil Analysis. New York: Soil Science Society of America, 961-1010.

Ping X Y, Zhou G S, Zhuang Q L, et al. 2010. Effects of sample size and position from monolith and core methods on the estimation of total root biomass in a temperate grassland ecosystem in Inner Mongolia. Geoderma. 155: 262-268.

Post W M, Kwon K C. 2000. Soil carbon sequestration and land-use change: processes and potential. Global Change Biology, 6(3): 317-327.

Santana V M, Baeza M J, Maestre F T. 2012. Seedling establishment along post-fire succession in Mediterranean shrublands dominated by obligate seeders. Acta Oecologica, 39: 51-60.

Simpson E H. 1949. Measurement of diversity. Nature, 163: 688.

Southgate R, Masters P, Seely M. 1996. Precipitation and biomass changes in the Namib Desert dune ecosystem. Journal of Arid Environments, 33(3): 267-280.

Steel R G D, Torrie J H. 1960. Principles and Procedures of Statistics With Special Reference to the Biological Sciences. Toronto: McGraw-Hill Book Company.

Süß K, Storm C, Zehm A, et al. 2004. Succession in inland sand eco- 
systems: Which factors determine the occurrence of the tall grass species Calamagrostis epigejos (L.) Roth and Stipa capillata L.? Plant Biology, 6(4): 465-476.

Swaine M, Whitmore T. 1988. On the definition of ecological species groups in tropical rain forests. Vegetation, 75(1-2): 81-86.

Ter Braak C J. 1989. CANOCO-an extension of DECORANA to analyze species-environment relationships. Hydrobiologia, 184(3): 169-170.

Tian G, Granato T, Cox A, et al. 2009. Soil carbon sequestration resulting from long-term application of biosolids for land reclamation. Journal of Environmental Quality, 38(1): 61-74.

Tropek R, Cerna I, Straka J, et al. 2013. Is coal combustion the last chance for vanishing insects of inland drift sand dunes in Europe? Biological Conservation, 162: 60-64.

Wang R Z, Earle A R, Zu Y G, et al. 2001. Demography of reproductive and biomass allocation of grassland and dune Leymus chinensis on the Songnen Plain, north-eastern China. Journal of Arid Environments, 49(2): 289-299.

Wang X B, Oenema O, Hoogmoed W B, et al. 2006. Dust storm erosion and its impact on soil carbon and nitrogen losses in northern China. Catena, 66: 221-227.

Xiao C W, Janssens I A, Liu P, et al. 2007. Irrigation and enhanced soil carbon input effects on below-ground carbon cycling in semiarid temperate grasslands. New Phytologist, 174 (4): 835-846.

Xie G H, Steinberger Y. 2005. Nitrogen and carbon dynamics under the canopy of sand dune shrubs in a desert ecosystem. Arid Land Research and Management, 19(2): 147-160.

Zhai S S, Liu Z M, Yan Q L. 2009. Effects of sand-barrier near interdune lowlands on the vegetation restoration of mobile sand dunes. Chinese Journal of Ecology, 28: 2403-2409. (in Chinese)

Zhang G L, Dong J W, Xiao X M, et al. 2012. Effectiveness of ecological restoration projects in Horqin Sandy Land, China based on SPOT-VGT NDVI data. Ecological Engineering, 38(1): 20-29.

Zhang J, Zhao H, Zhang T, et al. 2005. Community succession along a chronosequence of vegetation restoration on sand dunes in Horqin Sandy Land. Journal of Arid Environments, 62(4): 555-566.

Zhang T H, Zhao H L, Li S G, et al. 2004. A comparison of different measures for stabilizing moving sand dunes in the Horqin Sandy Land of Inner Mongolia, China. Journal of Arid Environments, 58(2): 203-214.

Zuo X A, Zhao H L, Zhao X Y, et al. 2008. Spatial pattern and heterogeneity of soil properties in sand dunes under grazing and restoration in Horqin Sandy Land, Northern China. Soil and Tillage Research, 99(2): 202-212. 